\title{
Is Whole-Mount Section in Rectal Cancer Effective for Measuring Lateral Margin?
}

\author{
Jun Seong Chung, Han Deok Kwak, Jae Kyun Ju \\ Department of Surgery, Chonnam National University Hospital, Gwangju, Korea
}

\section{See Articles on Page 172-177}

Total mesorectal excision (TME) was first described by Heald et al. [1] in 1982, and since then, TME has been the standard technique of rectal cancer surgery [2]. Since the introduction of this technique, it has contributed to reducing local recurrence and improving survival after rectal cancer surgery [3-5]. However, local recurrence remains a serious problem after rectal cancer surgery and affects the patient's quality of life [6]. Several studies reported that circumferential resection margin (CRM) involvement is a powerful predictor of local recurrence $[6,7]$. Therefore, in order to evaluate the exact radical resection of rectal cancer, the accuracy of CRM involvement and quality of completeness of TME are the most important $[8,9]$. According to the 8th edition of the American Joint Committee on Cancer staging manual published in 2018, a new nodal stage called "N1c" has been added. N1c indicates that the local lymph nodes are not positive, but there are tumor deposits in the subserosa, mesentery, or perirectal/mesorectal tissues. This means that tumor invasion into mesorectal tissue affects local recurrence and prognosis of rectal cancer. Several studies $[10,11]$ suggested that whole-mount sections provide a more accurate and effective assessment of rectal cancer, especially in the spread of the mesorectal region of the discontinuous microscopic tumor nodules compared to a conventional section. In addition, all whole-mount sections showed the overall morphological characteristics of the surgical specimen including the primary tumor, the bowel wall and the mesorectum. In a recent study, whole-mount sections were used to analyze lateral margins

Correspondence to: Jae Kyun Ju, M.D.

Department of Surgery, Chonnam National University Hospital, 42 Jaebong-ro, Dong-gu, Gwangju 61469, Korea

Tel: +82-62-220-6456, Fax: +82-62-227-1635

E-mail: jkju@jnu.ac.kr

ORCID: https://orcid.org/0000-0003-1605-3310

(C) 2020 The Korean Society of Coloproctology

This is an open-access article distributed under the terms of the Creative Commons Attribution NonCommercial License (https://creativecommons.org/licenses/by-nc/4.0) which permits unrestricted noncommercial use, distribution, and reproduction in any medium, provided the original work is properly cited. and micrometastasis more accurately for radical resection of rectal cancer [12]. They categorized the patients with perirectal tissue invasion by the 3 groups according to the length of the lateral margin (LM: $1 \mathrm{~mm}, 1.5 \mathrm{~mm}, 2 \mathrm{~mm}$ ). They analyzed recurrence, overall survival, disease specific survival and clinicopathologic features including lymphovascular invasion, perineural invasion and micrometastasis according to each group. In all groups, lymphovascular invasion was significantly frequent and the $\mathrm{N}$ state was higher when LM was short. There were more micrometastasis in group $\mathrm{LM} \leq 1 \mathrm{~mm}(53.3 \% \leq 1 \mathrm{~mm}$ vs. $26.6 \%>1 \mathrm{~mm}, \mathrm{P}=$ 0.039 ). And overall survival was worse when LM was short in each analysis based on $1 \mathrm{~mm}$ and $1.5 \mathrm{~mm}(\mathrm{P}<0.001)$. In all groups, disease specific survival was worse when LM was short.

In summary, the results of improvement in local recurrence and survival through TME technique in the treatment of rectal cancer are obvious, but inadequate resection margin or incomplete CRM causes poor prognosis of rectal cancer. Therefore, a precise pathologic examination method for accurate resection margin and incomplete CRM in rectal cancer is needed. According to recent study results, specimen analysis through the whole-mount section may be a more effective alternative to conventional section analysis for lateral margin measurement. Also, based on continuous additional studies, it may have a good effect on the prognosis of rectal cancer patients.

\section{CONFLICT OF INTEREST}

No potential conflicts of interest relevant to this article were reported.

\section{REFERENCES}

1. Heald RJ, Husband EM, Ryall RD. The mesorectum in rectal cancer surgery-the clue to pelvic recurrence? Br J Surg 1982;69:613-6.

2. Reynolds JV, Joyce WP, Dolan J, Sheahan K, Hyland JM. Pathological evidence in support of total mesorectal excision in the management of rectal cancer. Br J Surg 1996;83:1112-5.

3. Arbman G, Nilsson E, Hallböök O, Sjödahl R. Local recurrence following total mesorectal excision for rectal cancer. Br J Surg 


\section{6;83:375-9.}

4. Heald RJ, Ryall RDH. Recurrence and survival after total mesorectal excision for rectal cancer. Lancet 1986;1:1479-82.

5. Peeters KC, Marijnen CA, Nagtegaal ID, Kranenbarg EK, Putter $\mathrm{H}$, Wiggers $\mathrm{T}$, et al. The TME trial after a median follow-up of 6 years: increased local control but no survival benefit in irradiated patients with resectable rectal carcinoma. Ann Surg 2007;246: 693-701.

6. Nagtegaal ID, Marijnen CA, Kranenbarg EK, van de Velde CJ, van Krieken JH; Pathology Review Committee, et al. Circumferential margin involvement is still an important predictor of local recurrence in rectal carcinoma: not one millimeter but two millimeters is the limit. Am J Surg Pathol 2002;26:350-7.

7. Agger EA, Jörgren FH, Lydrup MLA, Buchwald PL. Risk of local recurrence of rectal cancer and circumferential resection margin: population-based cohort study. Br J Surg 2020;107:580-5.

8. Quirke P, Steele R, Monson J, Grieve R, Khanna S, Couture J, et al. Effect of the plane of surgery achieved on local recurrence in patients with operable rectal cancer: a prospective study using data from the MRC CR07 and NCIC-CTG CO16 randomised clinical trial. Lancet 2009;373:821-8.

9. Nagtegaal ID, Quirke P. What is the role for circumferential margin in the modern treatment of rectal cancer. Br J Surg 2009;96: 982-9.

10. Shimada Y, Takii Y. Clinical impact of mesorectal extranodal cancer tissue in rectal cancer: detailed pathological assessment using whole-mount sections. Dis Colon Rectum 2010;53:771-8.

11. Wang Z, Zhou Z, Wang C, Zhao G, Chen Y, Gao H, et al. Microscopic spread of low rectal cancer in regions of the mesorectum: detailed pathological assessment with whole-mount sections. Int J Colorectal Dis 2005;20:231-7.

12. Nam S, Hong Y, Choi YJ, Kang JG. Clinicopathologic analysis of lateral margin measured by whole-mount section in T3 rectal cancer. Ann Coloproctol 2020;39:172-7. 